\title{
THE COMPOSITION OF CARBOHYDRATE AND FAT CONSUMPTION AMONG OBESE ADOLESCENTS IN SURABAYA AND SIDOARJO
}

\author{
Christine Florens $^{1}$, Nur Aisiyah Widjaja ${ }^{*}$, Roedi Irawan ${ }^{1}$, Meta Herdiana Hanindita ${ }^{1}$ \\ ${ }^{1}$ Child Health Department, Faculty of Medicine, Universitas Airlangga, Dr. Soetomo General Hospital, Surabaya, Indonesia \\ *E-mail: nuri108@yahoo.com
}

\begin{abstract}
Carbohydrates and fats are macronutrients that have been the most influential factors to obesity. The excess of consumed carbohydrates or fats will be stored as triglycerides in adipocytes. This study aims to analyze the proportion of carbohydrates and fats consumption among obese adolescents from Surabaya and Sidoarjo. This study also revealed the relationship between the proportion with the total calories consumption and body mass index (BMI). This crosssectional study involved obese adolescents aged 13-18 years old from several junior and senior high schools, conducted during May-September 2020. The subject was selected using a total population sampling method that met inclusion and exclusion criteria. Anthropometries (weight and height) were measured to calculate BMI and determine obesity according to CDC 2000 criteria. A 24-hour-food-recall for the last two days was used to get the dietary information. This study divided carbohydrates consumption into three groups (high (HC), moderate (MC), low (LC)) and fats consumption into two groups (high fats (HF) and non-high fats (Non-HF)). There were 240 obese adolescents participating in this study; $40.4 \%$ of them consuming high carbohydrates and $17.5 \%$ of them consuming HF on their diets. Although there were several distinctions in carbohydrates and fats composition on diet, the total calorie and the mean BMI were not considerably different based on macronutrients consumption. In conclusion, there were two types of imbalance proportion of macronutrients consumption among our participants, high-carbohydrates-low-fats diet and low-carbohydrates-high-fats-diet.
\end{abstract}

Keywords: adolescents, carbohydrates, consumption, fats, obesity

\section{INTRODUCTION}

Obesity is the result of interaction between dietary patterns, environments, and genetic factors (Ghosh \& Bouchard, 2017). It is often handled by not only decreasing total calories consumption, but also arranging balance proportion of the macronutrients (Sjarif et al., 2014). Adolescents are considered to have imbalanced nutritional habits, such as consuming more sweet beverages, fast foods, and less fruits and vegetables. Such habits might have metabolic consequences and indeed experience obesity (Ruiz, et al., 2020). Based on Indonesia's national research on essential health, the obesity case in adolescents has increased two folds in five years (Kementrian Kesehatan RI, 2018).

Excessive consumption of carbohydrates, proteins, or fats possibly increase weight (Febriani et al., 2019). In connection with obesity, adipocytes are hypertrophy and become the storage of triglycerides (TG) (Bessesen et al., 2015). Human body cannot store excessive protein so that it will eventually be converted to glucose (via gluconeogenesis) or ketone. In a state of low energy demand, these metabolites will be stored as glycogens and fats (Clifton \& Keogh, 2007). Excessive carbohydrates will also be stored in the form of glycogens and fats (Febriani, et al., 2019).

Every population has its dietary habits that will impede the proportion of consumed macronutrients. Thus, many people have dissimilar types of diet disproportion (Villa, et al., 2015; Mank, et al., 2020).

This study aimed to analyze the proportion of carbohydrate and fat consumption among obese adolescents and reveal the relationship between total calories consumption and BMI. The imbalanced macronutrient patterns described in this study might be considered in conducting obesity management especially in adolescents. 


\section{METHODS}

This study used cross-sectional research design to address the research questions undertaken from May to September 2020. The research subjects included obese adolescents from 12 junior and senior high schools in Surabaya and Sidoarjo, East Java Province, Indonesia. The subjects were determined with a total population sampling method that met the inclusion and exclusion criteria. The minimum sample size was counted with formula for estimating a population proportion with specified absolute precision $n=Z_{1-\frac{\alpha}{2}}^{2} P(1-P) / d^{2}$. Using $1-\propto=95, \mathrm{~d}$ (size difference, minimal effect of interest) 0.1 , and $\mathrm{P}$ (true proportion) 0.5 . The minimal sample size is 97 .

The inclusion criteria were those adolescents aged 13-18 years with obesity problems. Moreover, the subjects, along with their parents, voluntarily participated in the present study. Adolescents with a history of corticosteroid consumption for more than two up to six months before the study was carried out or the subjects got sick, were excluded.

In accordance with the present study, obesity was determined based on the CDC 2000 criteria, which conveys that the BMI/age was above the $95^{\text {th }}$ percentile according to age and gender. Body weight was measured using a digital weight scale (Seca, Germany No ref. 224 1714009) with a precision of $0.1 \mathrm{~kg}$. Height measurement was performed using stadiometer (Seca, Germany No ref. 224 1714009), with an accuracy of $0.1 \mathrm{~cm}$. The proportion of each macronutrient in the diet was obtained from a 24-hour food recall interview by the researchers for two days $(2 \times 24$ hours, during weekdays), before the data retrieval process. All gathered data were then converted into total calories, amount of calories from carbohydrates, protein, and fat based on foods exchange list. Data on total calories and total macronutrients consumption were the averages of food recall information for two days. The proportion of carbohydrates was calculated based on the amount of caloric intake in the diet process derived from carbohydrates divided by the total caloric intake, then, multiplied by $100 \%$. The same way was used to determine the proportion of protein and fat in the diet process. Carbohydrate consumption was divided into three groups: (1) a high-carbohydrates
(HC) diet when the average energy intake of carbohydrates in the diet was more than $65 \%$, (2) moderate carbohydrates (MC) diet included the average energy intake of carbohydrates diet between $45-65 \%$, and (3) The low-carbohydrates (LC) diet group was an average energy intake from carbohydrates less than 44\% (Jung \& Choi, 2017). The fat consumption could be classified into two groups: a HF diet group and a non-high fat (HF) diet group. In a HF diet group, when the average energy intake came from fat in the diet, more than $30 \%$ of total calories consumed. The non-HF diet group was the total consumption of calories derived from fat $30 \%$ or less (Schwingshackl \& Hoffmann, 2013).

Total calories and macronutrient proportions were expressed in mean (M) and standard deviation (SD) when the normal distribution was attained. However, if the data were not normally distributed, the minimum and maximum median were used. The analysis of differences in macronutrient proportions based on carbohydrate and fat consumption group used One-way ANOVA, Kruskal-Wallis, t-test, and Mann-Whitney Test by the assistance of SPSS version 21.0. This study had got permission from the ethics committee of The Faculty of Medicine, Airlangga University No. 115/EC/KEPK/FKUA/ 2020. Before conducting the data collection, the researchers had explained to the subjects' parents about the general research information and had informed about the consent.

\section{RESULTS AND DISCUSSIONS}

There were 240 obese adolescents aged 13-18 years old involved in the present study consisted of boys $(52.1 \%)$ and girls (47.9\%). This study also classified the subjects by ages, of which there were $44.6 \%$ of them less than 15 years old and $55.4 \%$ older than or equals to 15 years old. The average of total calories consumed per day from all the subjects was $2474.8 \pm 416 \mathrm{kcal}$, with the composition of $61.7 \% \pm 10.5$ carbohydrates, $15.3 \% \pm 3.0$ proteins, and $22.3 \% \pm 9.8$ fats. The mean of carbohydrate consumption per day from all subjects was $383.9 \pm 141$ gram. The mean of fat consumption per day from all subjects was $66.8 \pm 45.7$ gram. The total calories consumed by boys were $2487 \pm 419 \mathrm{kcal}$ ( $62.4 \%$ carbohydrates, $15.5 \%$ proteins, and $20.1 \%$ fats) with mean of 
carbohydrates consumption per day $364.7 \pm 149.7$ gram and mean of fats consumption per day $52.7 \pm 34.3$ gram. Whereas, the total calories consumed by girls were $2461.6 \pm 414 \mathrm{kcal}(61.0 \%$ carbohydrates, $15.2 \%$ proteins, and $22.4 \%$ fats) with mean of carbohydrates consumption per day $404.9 \pm 129.3$ gram and mean of fats consumption per day $82.0 \pm 51.5$ gram. Both data conveyed by sexes were not significantly difference.

In accordance with the total calories consumed based on the age group, those in the less than 15 years old group consumed $2454.9 \pm 392 \mathrm{kcal}$ (61.3\% carbohydrates, $15.8 \%$ proteins, and $21.1 \%$ fats) with mean of carbohydrates consumption per day $397.3 \pm 141.5$ gram and mean of fats consumption per day $64.6 \pm 42.0$ grams. In the older group, the average of total calories consumption was $2490.9 \pm 435 \mathrm{kcal}(62.1 \%$ carbohydrates, $14.9 \%$ proteins, and $14.6 \%$ fats) with mean of carbohydrates consumption per day $373.3 \pm 141.2$ gram and mean of fats consumption per day $64.6 \pm 42.0$ gram. The average protein proportion on diet in the 15 years old or older group was significantly lower $(\mathrm{p}<0.03)$.

According to the carbohydrate and fat consumption categories, dietary compositions revealed no significant difference in total calorie (Table 1). A total of 15 students (6.3\%) consumed LC, 128 students $(53.3 \%)$ consumed MC, and 97 students $(40.4 \%)$ consumed $\mathrm{HC}$ diet. On the other hand, the total subjects with HF diet were 42 students $(17.5 \%)$, and the rest of them consumed fats less than $30 \%$ (Non-HF).

The number of fats and protein consumption differed significantly based on carbohydrates consumption (see Table 2). The LC group consumed 356.8 \pm 128.3 -gram carbohydrate and $72.9 \pm 44.2$-gram fats per day. The MC group

Table 1. Total Calories Consumptions based on Carbohydrates and Fat Diets Category

\begin{tabular}{lcc}
\hline \multicolumn{2}{c}{ Total Calories (kcal) } & p \\
\hline \multicolumn{2}{c}{ Carbohydrate diet categories } \\
LC & $2460.9 \pm 355$ \\
MC & $2503.9 \pm 427$ & \\
HC & $2438.6 \pm 410$ & \\
Fat diet categories & \\
HF & $2570 \pm 520$ & \\
Non-HF & $2454 \pm 389$ & 0.10 \\
\hline
\end{tabular}

Table 2. Fat and Protein Proportions According to Carbohydrates Consumption on Diet

\begin{tabular}{lcc}
\hline Carbohydrate Diet & Fat Proportions (\%) & p \\
\hline LC & $45.4 \%(31.8-54.5 \%)$ & \\
MC & $16.1 \%(9.1-25.1 \%)$ & 0.00 \\
HC & $13.6 \%(8.3-18.8 \%)$ & \\
\hline Carbohydrate Diet & Protein Proportions (\%) & p \\
\hline LC & $16.7 \% \pm 2.9$ & \\
MC & $16.4 \% \pm 2.9$ & \\
HC & $13.7 \% \pm 2.4$ & 0.00 \\
\hline
\end{tabular}

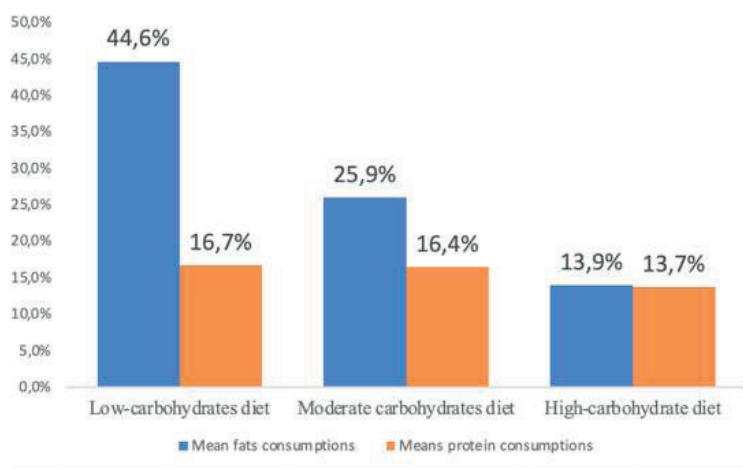

Figure 1. Means of Fat and Protein Proportion based on Carbohydrate Consumption Categories

consumed 381.1 \pm 161.5 -gram carbohydrates and fats $60.2 \pm 41.0$-gram per day. The HC group consumed $404.8 \pm 146.1$ gram carbohydrates and $59.7 \pm 47.7$-gram fats per day.

Subjects in the LC group consumed higher fats than the other two groups based on carbohydrates proportion on a diet. In contrast, the HC diet group consumed significantly lower fats and proteins (see Figure 1). Based on the fat proportion on diet, the HF diet group consumed fewer carbohydrates proportion than the Non-HF diet group (see Table $3)$.

Table 3. Carbohydrate and Protein Proportions According to Fat Consumptions on Diet

\begin{tabular}{lcc}
\hline \multicolumn{1}{c}{ Fat diet } & Carbohydrate proportions (\%) & p \\
\hline HF & $46.9 \% \pm 6.1$ & 0.00 \\
Non-HF & $64.9 \% \pm 8.2$ & \\
\hline \multicolumn{1}{c}{ Fat diet } & Protein proportions (\%) & p \\
\hline HF & $16.0 \% \pm 2.7$ & 0.10 \\
Non-HF & $15.2 \% \pm 3.1$ & \\
\hline
\end{tabular}




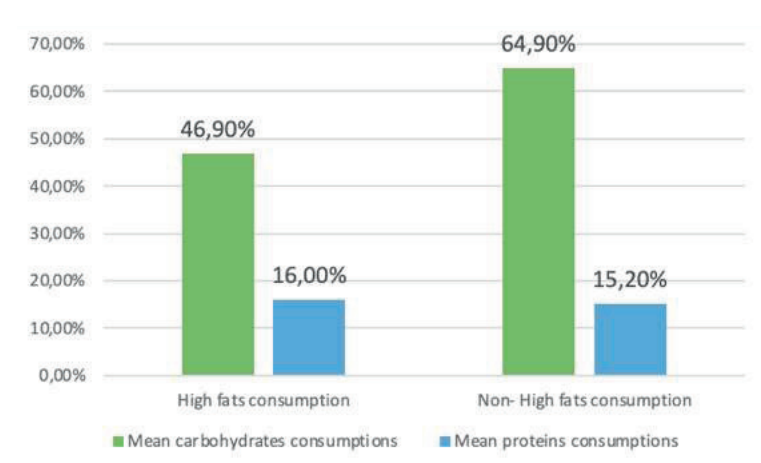

Figure 2. Means of Carbohydrate and Protein Proportion based on Fats Consumption Categories

The HF group consumed 68.36 \pm 48.1 -gram fats and $379.8 \pm 138.8$-gram carbohydrates per day. The Non-HF group consumed 59.3 \pm 31 .6-gram fats and 403.3 \pm 153.9 -gram carbohydrates per day. On the other hand, the proportion of protein consumptions between the two groups did not significantly different (see Table 3 and Figure 2). The carbohydrate proportion on diet in the NonHF group was significantly higher than the HF diet group (see Figure 2). In regard to BMI, there was no significant difference from the average BMI based on the proportion of fats and carbohydrates consumption in the diet (see Table 4).

Adolescents are less likely to achieve a balanced nutrient consumption that could increase the risk of obesity. Obesity at the age of 12-19 years might negatively impact the form of excessive fatty tissue that can manifest in hypertension, hyperglycemia, and dyslipidemia (Ruiz et al., 2020). Recommended composition of different macronutrients ranges from $45 \%$ to $65 \%$ of carbohydrates, $25 \%$ to $35 \%$ of fats, and

Table 4. Relationship between Carbohydrate and Fat Proportion on Diet with BMI in Obese Adolescents

\begin{tabular}{|c|c|c|}
\hline & BMI $\left(\mathrm{kg} / \mathrm{m}^{2}\right)$ & $\mathbf{p}$ \\
\hline \multicolumn{3}{|c|}{ Carbohydrate Diet Categories } \\
\hline LC & $31.5(27.0-44.7)$ & \multirow{3}{*}{0.82} \\
\hline $\mathrm{MC}$ & $31.4(25.3-47.8)$ & \\
\hline $\mathrm{HC}$ & $32.2(25.3-44.6)$ & \\
\hline \multicolumn{3}{|c|}{ Fat Diet Categories } \\
\hline $\mathrm{HF}$ & $31.5(25.3-45.6)$ & \multirow{2}{*}{0.99} \\
\hline Non-HF & $31.7(25.3-47.8)$ & \\
\hline
\end{tabular}

$10 \%$ to $20 \%$ of proteins (Kim \& Chung, 2020). The recommended balanced macronutrient composition based on the Indonesian Pediatric Society Guidelines on management of obesity should contain $50-60 \%$ of carbohydrates, $30 \%$ of fats, and $15-20 \%$ of proteins (Sjarif et al., 2014). This study portrays that the subjects' average carbohydrates consumption as obese adolescents was slightly above the recommendations $(61.7 \%$ $\pm 10.5)$ with an average protein consumption of $15.3 \% \pm 3.0$ and an average fat consumption of $22.3 \% \pm 9.8$. This average fat consumption was also slightly lower than the recommendation from Indonesian Pediatric Society. Based on these data, the management of obesity should give special attention to macronutrients proportion. In normalizing our adolescents diet proportion, the decrease in carbohydrate consumption must be accompanied with increasing consumption of several food ingredients containing fats in the form of Polyunsaturated Fatty Acid (PUFA), like omega-3 and omega- 6 .

In addition, the subjects' average total calories consumption was $2487 \pm 419 \mathrm{kcal}$ for boys and $2461 \pm 414 \mathrm{kcal}$ for girls. Ozdemir (2016) stated that the average daily calories needed for female adolescents ranged from $1800-2500 \mathrm{kcal}$ and 2500-3500 kcal for male adolescents. The daily calories based on Indonesian Minister of Health regulation No.28 in year 2019, the male adolescent age 13-18 years-old need $2400-2650 \mathrm{kcal}$ and female adolescent in the same age need 2050-2100 $\mathrm{kcal}$. Thus, the average total calories in obese adolescents were within the recommended range in boys but higher than recommended range in girls. In addition to calories intake, the amount of physical activity also needs to be further considered as a cause of obesity.

This study also found that there were no significant differences in the composition of macronutrient consumption between boys and girls and between age groups. However, there was a significant difference found in the low-protein consumption in the age group of 15 years or older compared to those in the age group of less than 15 years. The decrease in the amount of protein consumption was followed by an increase in the number of carbohydrates consumed in the same age group. 
WHO recommends the consumption of 0.8 grams $/ \mathrm{kg} /$ day of protein in female adolescents and in male $1.0 \mathrm{grams} / \mathrm{kg} / \mathrm{day}$. The needs of protein in adolescents increases due to the increasing muscle age and hormonal changes. In female adolescent, the needs of protein are higher at the age of 11-14 years old, while the demand for protein increases at the age of 15-18 years old for male. It is recommended that $50 \%$ of protein needs contain $50 \%$ of vegetable proteins and $50 \%$ of animal proteins. Most of animal protein sources can be obtained from dairy products (70-80\%) (Ozdemir, 2016).

Dror \& Allen (2014) found that proteins consumption, especially in dairy products, decrease along with the increasing ages. One of the influential factors that affects the decrease milk consumption in adolescents is the consumption of sweet beverages and fruit juices that substitute the consumption of the dairy products (Dror \& Allen, 2014). However, in general, the amount of protein consumed in this study was close to the recommended amount which is $15-20 \%$ of total daily energy derived from protein (Sjarif et al., 2014). This study also conveyed that the difference in the amount of protein consumption based on age could be caused by the same thing, where the amount of protein consumption appeared to decrease in the diet undertaken by the high carbohydrate-consumption group.

Another study found that high carbohydrate consumption in adolescents did not significantly increase the risk of overweight/obesity than the excessive consumption of fats and proteins (Febriani et al., 2019). The role of excessive carbohydrate composition on the risk of obesity is still on a debate. A systematic review and metaanalysis have not concluded whether a diet of high carbohydrates increases the risk of obesity (Sartorius et al., 2018). However, evidence has been found that the obesity cases have increased along with ascending production of foods containing carbohydrates and sugars. Thus, people should be aware of carbohydrate types that contribute to increasing the risk of obesity. Adolescents are particularly susceptible to the habits of consuming simple carbohydrates and sugars, one of which is through the consumption of sweet beverages. Consumption of sweet beverages has increased by $300 \%$ in the last 20 years, and $56-85 \%$ of school children consumed at least one serving per day. Consumption of a glass of sweet beverages will increase the risk of obesity 1.6 times. Such relationship is related to high sugar content, no satiety, and a high glycemic index. A high glycemic index contributes to obesity in adolescents through increasing insulin resistance and excessive energy (Harrington, 2008; Keller \& Torre, 2015). This study did not distinguish the types of carbohydrates consumed as simple carbohydrates or complex carbohydrates. Rather, the study used the entire subjects of obesity, so that it was unable to analyze the increasing risk of obesity due to a $\mathrm{HC}$ diet. However, this study showed that there was an imbalance of macronutrient intake in obese adolescents.

In the $\mathrm{HC}$ diet group, fat and protein intake decreased. Meanwhile, in the low-carbohydrate diet group, the fat intake increased (see Figure 1 and 2). Thus, two types of dietary imbalances were obtained in this study, a high-carbohydrateslow-fats and low-carbohydrates-high-fats dietary pattern. A diet of high carbohydrates consumption is similar to a typical Korean diet with white rice as the main dish. Increasing consumption of carbohydrates and low fats is not associated with an increasing risk of obesity. However, it is associated with increasing triglycerides and decreasing HDL (Lee, Song, and Song, 2018). Merchant et al. (2009) precisely found that individuals who consumed carbohydrates less than or equal to $47 \%$ of total daily calorie consumption had a greater risk of being overweight and obese than those who consumed $47-64 \%$ of total daily calories. This may be due to individuals who consumed more carbohydrates had more fruits and vegetable intakes (Merchant et al., 2009). Other studies suggested that a person who consumed enough fruits and vegetables had a lower risk of being obese than those who consumed less fruits and vegetables, regardless the amount of fat consumption (Ledikwe et al., 2006).

A HF diet was stated as one of the central obesity risk factors, especially in women (Sun \& $\mathrm{Su}, 2020)$. A HF diet increased the risk of obesity by 1.2 times $(95 \% \mathrm{CI}: 1.1-1.4)$ (Roman et al., 2019). The influence of both types of dietary imbalances on obesity may be related to hunger 
and satiety. In accordance with the comparison of high-fats-low-carbohydrates dietary patterns and low-fats-high-carbohydrates dietary patterns in overweight and obese individuals, Hopkins et al. (2016) showed the total amount of energy consumed in high-fats-low-carbohydrates diets was higher but lacks of satiety. Moreover, a highcarbohydrates diet provided more satiety (Hopkins et al., 2016).

This study also depicted that there was no significant difference in BMI based on the number of carbohydrates or fats consumption. In line with Ibrahim et al (2019), total calorie intake and macronutrient amounts were not associated with the degree of obesity described with BMI. Similar results were also obtained in Korea (Kim \& Song, 2019). As opposed to Lyles et al. (2006), BMI was related to the consumption of proteins and carbohydrates. These differences may be related to population differences in the undertaken research. This study involved only obese adolescents and did not include adolescents with normal BMI, so that it could not adequately see the relationship between macronutrient consumption with BMI.

The differences found in the present study results might occur due to using the classification of HC and HF diet. However, there was the data collection on dietary macronutrients obtained by using the 24-hours food recall method, which had a high risk of recall bias caused by the different perception between the portion of food consumed by the subjects and the amount meant by the researchers. To overcome this lacks, the researchers used food models during the interview process. To address the risk of under-reporting food recall, this study used a $2 \times 24$-hours food recall. This period of times can estimate daily dietary intake that is significantly closer to daily energy expenditure than a once 24-hour food recall (Ma et al., 2009).

Further study will be needed by considering the interaction of physical activity and macronutrients consumption as a cause of obesity.

\section{CONCLUSION}

Generally, the obese adolescents consumed higher amount of carbohydrates and less amount of fat based on recommendation from
Indonesian Pediatric Society. There were two types of imbalance proportion of macronutrients consumption among our participants, highcarbohydrates-low-fats diet and low-carbohydrateshigh-fats-diet. The macronutrients proportion might consider in management of obesity, not only for decreasing body weight but also preventing the dyslipidemia in obese adolescents.

\section{ACKNOWLEDGEMENT}

This research is part of a thesis conducted by Widjaja et al. (2020). Author would like to thank the 12 high schools in Surabaya and Sidoarjo who volunteered as respondents. We would thank all headmasters and counselling teachers who gathered our respondents along with their parents with us before and during the data collection.

\section{REFERENCES}

Bessesen, D. H., Cox-York, K.A., Hernandez, T.L., Erickson, C.B., Wang, H. J., Jackman, M.R., \& Van Pelt, R.E. (2015). Postprandial triglycerides and adipose tissue storage of dietary fatty acids: Impact of menopause and estradiol. Obesity, 23(1), 145-53. doi: 10.1002/oby.20935

Clifton, P. M. \& Keogh, J. (2007). Metabolic effects of high-protein diets. Curr Atheroscler Rep, 9(6), 472-78. doi: 10.1007/s11883-0070063-y

Dror, D. K. \& Allen, L.H. (2014). Dairy product intake in children and adolescents in developed countries: trends, nutritional contribution, and a review of association with health outcomes. Nutr Rev, 72(2), 68-81. doi: 10.1111/nure.12078.

Febriani, R.T., Soesetidjo, A., \& Tiyas, F. W. (2019). Consumption of fat, protein, and carbohydrate among adolescent with overweight/ obesity. JMCH, 70-6. doi: 10.26911/ thejmch.2019.04.02.02.

Ghosh, S. \& Bouchard, C. (2017). Convergence between biological, behavioural and genetic determinants of obesity. Nat Rev Genet, 18(12), 731-748. doi: 10.1038/nrg.2017.72.

Hamdy, O., Tasabehji, M.W., Elseaidy, T., Tomah, S., Ashrafzadeh, S., \& Mottalib, A.(2018). Fat versus carbohydrate-based energy restricted diets for weight loss in patients with type 2 diabetes. Curr Diab Rep, 18(12), 128-32. doi: 10.1007/s11892-018-1103-4.

Harrington, S. (2008). The role of sugar-sweetened 
beverage consumption in adolescent obesity: A review of the literature, $J$ Sch Nurs, 24(1), 3-12. doi: 10.1177/10598405080240010201.

Hopkins, M., Gibbons, C., Cudwell, P., et al. (2016). Differing effects of high-fat or high-carbohydrate meals on food hedonics in overweight and obese individuals. Br J Nutr, 115(10), pp. 1875-84. doi: 10.1017/S0007114516000775.

Ibrahim, R. H., Hendarto, A., Bardosono, S., et al. (2019). Hubungan asupan kalori total dan makronutrien dengan derajat obesitas pada remaja obesitas usia 14-18 tahun di Jakarta. Sari Pediatri, 21(3), 159-63. doi: 10.14238/ sp21.3.2019.159-63.

Jung, C. H. \& Choi, K. M. (2017). Impact of high-carbohydrate diet on metabolic parameters in patients with type 2 diabetes. Nutrients, 9(4), 2-21. doi: 10.3390/nu90403 22.

Keller, A. \& Torre, S. B. (2015). Sugar-sweetened beverages and obesity among children and adolescents: A review of systematic literature reviews, Child Obes, 11(4), 338-46. doi: 10.1089/chi.2014.0117.

Kementrian Kesehatan RI. (2018). Laporan nasional RISKESDAS 2018. Jakarta : Badan Penelitian dan Pengembangan Kesehatan Kementrian Kesehatan RI.

Kim, H. N. \& Song, S. W. (2019) Associations between macronutrient intakes and obesity/ metabolic risk phenotypes: findings of the korean national health and nutrition examination survey. Nutrients, 11(3), 1-11. doi: 10.3390/ nu11030628.

Kim, O. Y., Kim, E. M. \& Chung, S. (2020). Impacts of dietary macronutrient pattern on adolescent body composition and metabolic risk: current and future health status-A narrative review. Nutrients. 12(12), 1-16. doi: 10.3390/nu12123722.

Ledikwe, J. H., Blanck, H.M., Khan, L.K., Serdula, M.K., Seymour, J.D., Tohill, B.C., \& Rolls, B.J. (2006). Dietary energy density is associated with energy intake and weight status in US adults, Am J Clin Nutr, 83(6), 1362-68. doi: 10.1093/ajcn/83.6. 1362.

Lee, Y. J., Song, S. \& Song Y. (2018). Highcarbohydrate diets and food patterns and their associations with metabolic disease in the Korean population, Yonsei Med J, 59(7), 834-42. doi: 10.3349/ymj.2018.59. 7.834.

Lyles, $3^{\text {rd }}$, T. E., Desmond, R., Faulk, L.E., Henson, S., Hubbert, K., Heimburger, D.C., \& Ard, J.D. (2006). Diet variety based on macronutrient intake and its relationship with body mass index. MedGenMed. 8(3), 39 Retrieved from https:// pubmed.ncbi.nlm.nih. gov/17406172/

Ma, Y., Olendzki, B.C., Pagoto, S.L., Hurley, T.G., Magner, R.P., Ockene, I.S., Schneider, K.L., Merriam, P.A., \& Hebert, J.R. (2009). Number of 24-hour diet recalls needed to estimate energy intake. Ann of Epidemiol, 19(8), 553-9.doi: 10.1016/j.annepidem. 2009.04. 010

Mank, I., Vandormael, A., Traore, I., Ouédraogo, w.A., Suerborn, R., \& Danquah, I. (2020). Dietary habits associated with growth development of children aged $<5$ years in the Nouna Health and Demographic Surveillance System, Burkina Faso, Nutrition Journal, 19(1), 1-14. doi: 10.1186/s12937-020-00591-3.

Merchant, A. T. Vatabparast, H., Barlas, S., Dehghan, M., Ali Shah, S.M., De Koning, L., \& Steck, S.E. (2009). Carbohydrate intake and overweight and obesity among healthy adults, $J$ Am Diet Assoc, 109(7), 1165-72. doi: 10.1016/j. jada.2009.04.002.

Ozdemir, A. (2016). Macronutrients in adolescence. International Journal of Caring Sciences, 9(3), 1162-7. Accesed from www.internationalj ournalofcaringsciences.org.

Roman, G., Rusu, A., Graur, M., Creteanu, G., Morosanu, M., Radulian, G., Amorin, P., Timar, R., Pircalaboiu, L., \& Bala, C. (2019). Dietary patterns and their association with obesity: A cross-sectional study. Acta Endocrinol (Buchar), 15(1), 86-95. doi: 10.4 183/aeb.2019.86.

Ruiz, L. D., Zuelch, M.L., Dimitratos, S.M., \& Scherr,R.E. (2020). Adolescent obesity: diet quality, psychosocial health, and cardiometabolic risk factors. Nutrients, 12(43), 1-22. doi: 10.3390/nu12010043

Sartorius, K., Sartorius B., Madiba, T.E., \& Stefan, C. (2018). Does high-carbohydrate intake lead to increased risk of obesity? A systematic review and meta-analysis. BMJ Open, 8(2), 1-10. doi:10.1136/bmjopen-2017018449.

Schwingshack1, L \& Hoffmann, G. (2013). Comparison of effects of long-term low-fat vs high-fat diets on blood lipid levels in overweight or obese patients: A systematic review and meta-analysis. Journal of the Acad of Nutr Diet, 113(12), 1640-61.doi: 10.1016/j.jand.2013 .07 .010

Sjarif, D. R., Gultom, L.D., Hendarto, A., Lestari, E.D., Sidiartha, I.G.L., \& Mexitalia, M. (2014) Diagnosis, Tata Laksana dan Pencegahan Obesitas. (first edition), Ikatan Dokter Anak 
Indonesia. Jakarta: Ikatan Dokter Anak Indonesia.

Villa, J. K. D., Santos, T.S.S., Ribeiro, A.Q., E Silva, A.R., Pessoa, M.C., \& da Rocha Sant'Ana, L.F. (2015). Dietary patterns of children and socioeconomical, behavioral and maternal determinants. Revista Paulista de
Pediatria (English Edition), 33(3), 302-309. doi: 10.1016/j.rppede.20 15.06.012.

Zhao, J., Sun, J \& Su, C. (2020). Gender differences in the relationship between dietary energy and macronutrients intake and body weight outcomes in chinese adults. Nutrition Journal, 19(1), 1-9. doi: 10.1186/s12937-020-00564-6. 